\title{
Behçet's Disease and Anti-neutrophil Cytoplasmic Antibody (ANCA)-Associated Vasculitis
}

\author{
Duriye Deren Oygar ${ }^{1}$ and Yonca Morris ${ }^{2}$
}

\begin{abstract}
Behçet's disease (BD) is a multisystem disorder of unknown etiology. Renal involvement in Behçet's disease is not frequent. Pauciimmune necrotizing and crescentic glomerulonephritis is associated with antineutrophil cytoplasmic antibodies (ANCA) which are believed to activate neutrophils and cause vasculitis, especially if there is a concurrent synergistic inflammatory process. In this case report, we describe a patient diagnosed with $\mathrm{BD}$ who also developed pauciimmune necrotizing and crescentic glomerulonephritis. We also compared this case with similar previous cases reported in the literature. The aim of this study is to add information regarding ANCA, pauciimmune glomerulonephritis and Behçet's disease.
\end{abstract}

Key words: Behçet's, antineutrophil-cytoplasmic antibody, pauciimmune necrotizing and crescentic glomerulonephritis

(Intern Med 55: 2225-2228, 2016)

(DOI: 10.2169/internalmedicine.55.5413)

\section{Introduction}

Behçet's disease (BD) is a multisystem disorder of unknown aetiology. It is characterised by recurrent oral aphtous ulcers and any of several systemic manifestations, such as genital ulcers, uveitis, skin lesions, arthritis or vascular disease $(1,2)$. The disease was first described by Hippokrates, but it was introduced to the modern medical era by Hulusi Behçet in 1937 (3, 4)

Although the aetiology and pathogenesis of this disease is unknown, it is believed to be due to aberrant immune activity triggered by exposure to an agent, such as an infection, in patients genetically predisposed to develop the disease (5).

Renal involvement in Behçet's disease is not very frequent. The spectrum of renal diseases associated with this disease can be AA amyloidosis, glomerulonephritis, vascular disease and interstitial nephritis. Glomerulonephritis can vary from asymptomatic hematuria and/or proteinuria to rapidly progressive glomerulonephritis (RPGN) $(6,7)$.

Pauciimmune necrotizing and crescentic glomerulonephritis is known to be associated with anti-neutrophil cytoplas- mic antibodies (ANCA). Animal studies have shown that ANCA can activate neutrophils and cause vasculitis, especially if there is a concurrent synergistic inflammatory process, such as an infection (8).

There are several reports describing ANCA associated pauciimmune glomerulonephritis in patients with Behçet's disease (9-12). The relationship between ANCA and Behçet's is unknown. The aim of this study is to add information regarding the relationship among ANCA, pauciimmune glomerulonephritis and Behçet's disease.

\section{Case Report}

A 31-year-old, Turkish male patient visited our outpatient department complaining of frequent oral aphtous ulcers, genital ulcers, a swollen and painful left cuff, pustler skin eruptions and lower back pain. He had experienced recurrent oral ulcers for 2 years and genital ulcers for 6 months. His left cuff was swollen and had been painful for two weeks. On physical examination, two minor oral ulcers and one left scrotal ulcer were found. His left cuff was swollen and painful and Hoffman's sign was found to be positive, which is consistent with deep vein thrombosis (DVT). The Pathergy

${ }^{1}$ Nephrology Department, Nicosia General Hospital, Burhan Nalbantoglu Hospital, Cyprus and ${ }^{2}$ Rheumatology Department, Nicosia General Hospital, Burhan Nalbantoglu Hospital, Cyprus

Received for publication April 4, 2015; Accepted for publication November 23, 2015

Correspondence to Dr. Duriye Deren Oygar, derenoygar@yahoo.com 
test was positive. This patient, with his clinical findings, was this considered to fulfil the diagnostic criteriae of BD according to the International Study Group Criteria (ISG).

On admission, the laboratory test results were as follows: White blood cell count; 8,900/mcL, hemoglobin; $12.3 \mathrm{gr} / \mathrm{dL}$, blood urea nitrogen; $30 \mathrm{mg} / \mathrm{dL}$, serum creatinine; $1.6 \mathrm{mg} /$ $\mathrm{dL}$, serum albumin; $3.3 \mathrm{gr} / \mathrm{dL}$, C-reactive protein (CRP);24 $\mathrm{mg} / \mathrm{dL}$, erythrocyte sedimentation rate (ESR); $50 \mathrm{~mm} / \mathrm{hr}, \mathrm{C} 3$; $154 \mathrm{mg} / \mathrm{dL}, \mathrm{C} 4 ; 94 \mathrm{mg} / \mathrm{dL}$. Urinalysis revealed albuminuria with a dipstick and 8-10 erythrocytes on microscopy. His hepatitis serological tests were all negative. Antinuclear antibody (ANA) test, anti-cardiolipin antibodies and cryoglobulins were all found to be negative. ANCA was found to be positive with a cytoplasmic pattern (c-ANCA) on immunfluorescence and enzyme-linked immunosorbent assay (ELISA) tests and with a PR3 titre of 1/640. Chest radiography and abdominal ultrasonography (USG) were normal however his doppler USG of the lower extremities revealed bilateral DVT. The findings of thorax and sinus computed tomography were normal.

The patient was hospitalized and we started to administer colchicum dispert $1.5 \mathrm{mg} /$ day, oral methylprednisolone 1 $\mathrm{mg} / \mathrm{kg} /$ day, azathioprine $150 \mathrm{mg} /$ day and low molecular weight heparin for his DVT.

In the follow-up, his creatinine level increased, and on the third day of his admission it was $4.6 \mathrm{mg} / \mathrm{dL}$ while his albumin level was lowered to $2.6 \mathrm{gr} / \mathrm{dL}$ and his 24 hour urine collection revealed $4.5 \mathrm{gr} /$ day protein loss. He developed nephrotic syndrome and acute kidney injury. He began haemodialysis treatment on the 4th day and underwent a renal biopsy on the 5th day of admission. A kidney biopsy was performed and 6 glomeruli were examined. Light microscopy of a kidney biopsy specimen revealed parietal epithelial cell proliferation and fibrosis, showing a crescentic pattern with no segmental sclerosis. Crescents were present in $3(50 \%)$ of the glomeruli. Immunofluorescence microscopy revealed no deposits for IgG, IgM, IgA, C3, C1q, fibrinogen, Kappa or Lambda. Tubulointerstitial lesions consisted of mononuclear cell infiltration with few eosinophils, but no vasculitic pathology. The pathological diagnosis was crescentic glomerulonephritis with a pauciimmune character.

Thereafter, azathoprine was stopped and the patient was given pulse steroids $500 \mathrm{mg} /$ day for 3 days followed by 1 $\mathrm{mg} / \mathrm{kg} /$ day oral prednisolone and $1 \mathrm{gr}$ intravenous cyclophosphamide every 3 weeks. All clinical findings and the renal function improved within 15 days of the treatment, and therefore he no longer required any further dialysis. He was discharged with a serum creatinine level of $2 \mathrm{mg} / \mathrm{dL}$ and a 24-hour urine protein level of 3gr/day.

He was given pulse cyclophosphamide 6 times together with oral methylprednisolone which was slowly tapered to 5 $\mathrm{mg} /$ day. On the 6th month of the treatment his serum creatinine level was $1.1 \mathrm{mg} / \mathrm{dL}$, 24-hour urine protein was 500 mg/day and the PR3 titre was 1/20. Then the cyclophosphamide treatment was switched to azathioprine $150 \mathrm{mg} /$ day while he was still on $5 \mathrm{mg} /$ day methylprednisolone and an angiotensin converting enzyme inhibitor was also added to the treatment.

He was followed up by the rheumatology and nephrology departments for 3 years during which he was able to maintain a normal renal function with a mean proteinuria of 1.2 gr/day without any clinical complaints.

\section{Discussion}

This patient was considered to fulfil the diagnostic criteria of BD according to ISG and he also had c-ANCA associated pauciimmune glomerulonephritis, which was consistent with microscopic polyangiitis (Figure).

The frequency of renal problems among Behçet's Disease patients has been reported to vary between $0-55 \%$ (12-15). The spectrum of renal involvement in Behçet's disease can vary from hematuria, mild proteinuria to RPGN. A case that had Behçet's disease and RPGN was first reported by Kansu et al. in 1977 (16). Since then many other Behçet's disease patients with RPGN, mostly immune complex mediated (17-21), and four c-ANCA- associated (9-12) have been reported. Other cases of Behçet's diseases with c-ANCA, but no evidence of renal involvement, have also been reported (22). The properties of these four c-ANCA associated glomerulonephritis cases can be seen in Table. Almost all of the patients were treated as ANCA associated vasculitis (AAV) with steroids and cyclophoshamide and none of them had either upper or lower respiratory tract involvement. These patients were followed up for a varying time spans of 2 to 24 months, with varying prognoses (from a normal renal function to chronic renal failure, even to end stage renal failure requiring transplantation). Our patient maintained a normal renal function at least for 3 years.

The strong association of ANCA with small vessel vasculitis raises the possibility that it may be involved in the pathogenesis. The clinical and animal data support the hypothesis that activated neutrophils by ANCA can cause vasculitis, especially if there is a concurrent synergistic proinflammatory stimulus $(23,24)$. In this patient, the inflammatory status of Behçet's disease may have stimulated ANCA which thereby activate neutrophils and cause vasculitis in genetically predisposed patients.

In conclusion, our patient with c-ANCA positive RPGN, was therefore diagnosed to have Behçet's disease with ANCA positive paucimmune glomerulonephritis. In fact both of these conditions can be treated in the same way, namely with steroids and cyclophosphamide.

Behçet disease is not classified as an AAV and renal involvement is rare. Although there are different views on this matter, we believe that the pathogenesis of the involvement of ANCA in a patient with Behçet's disease needs further investigation $(9,10)$. However, this case, as with other similar cases in the literature, shows that renal involvement, although not frequent, must be evaluated and treated in cases presenting with Behçet's disease. The laboratory parameters mostly show proteinuria and hematuria, but involvement can 
Table. Case Reports of c-ANCA Associated Glomerulonephtitis in Behçet's Disease.

\begin{tabular}{|c|c|c|c|c|c|c|c|}
\hline Reference & Age & Sex & $\begin{array}{l}\text { Creatinine } \\
\text { at } \\
\text { admission } \\
(\mathrm{mg} / \mathrm{dL})\end{array}$ & $\begin{array}{l}\text { Extrarenal } \\
\text { involvement }\end{array}$ & Biopsy & Treatment & $\begin{array}{l}\text { Prognosis } \\
\text { (renal } \\
\text { function) }\end{array}$ \\
\hline 9 & 48 & $\mathrm{~F}$ & 5.7 & $\begin{array}{l}\text { Arthritis, } \\
\text { uveitis, oral and } \\
\text { genital aphtous } \\
\text { ulcers }\end{array}$ & $\begin{array}{l}\text { Pauciimmune } \\
\text { glomerulonephrit } \\
\text { is }\end{array}$ & $\begin{array}{l}\text { Solmuderol, } \\
\text { plasmapheresis, } \\
\text { cyclophosphamid } \\
\text { e pulse }\end{array}$ & $\begin{array}{l}3.4 \mathrm{mg} / \mathrm{dL} \text { at } 2 \\
\text { months }\end{array}$ \\
\hline 10 & 44 & M & 1.7 & $\begin{array}{l}\text { Arthritis, uveitis, } \\
\text { oral and genital } \\
\text { aphtous ulcers } \\
\text { ulcers }\end{array}$ & Normal & $\begin{array}{l}\text { Prednisiolone, } \\
\text { oral } \\
\text { cyclophosphamid } \\
\text { e }\end{array}$ & $\begin{array}{l}2.8 \mathrm{mg} / \mathrm{dL} \text { at } \\
14 \text { months }\end{array}$ \\
\hline 11 & 22 & $\mathrm{~F}$ & 1.2 & $\begin{array}{l}\text { Arthritis, } \\
\text { erythema } \\
\text { nodosum, } \\
\text { panniculitis, } \\
\text { aphtous ulcers }\end{array}$ & $\begin{array}{l}\text { Trace staining for } \\
\text { IgG, IgA }\end{array}$ & Prednisolone & $\begin{array}{l}\text { Normal renal } \\
\text { function at } 42 \\
\text { months }\end{array}$ \\
\hline 12 & 27 & M & 14 & $\begin{array}{l}\text { Arthritis, } \\
\text { Uveitis, aphtous } \\
\text { ulcers }\end{array}$ & $\begin{array}{l}\text { Puciimmune } \\
\text { glomerulonephrit } \\
\text { is }\end{array}$ & $\begin{array}{l}\text { Prednisolone, } \\
\text { cyclophosphamid } \\
\text { e }\end{array}$ & $\begin{array}{l}\text { Transplantatio } \\
\mathrm{n} \text { at 1year }\end{array}$ \\
\hline Our Case & 31 & M & 1.6 & $\begin{array}{l}\text { Arthritis, } \\
\text { uveitis, oral and } \\
\text { genital aphtous } \\
\text { ulcers }\end{array}$ & $\begin{array}{l}\text { Pauciimmune } \\
\text { glomerulonephrit } \\
\text { is }\end{array}$ & $\begin{array}{l}\text { Prednisolone, } \\
\text { cyclophosphamid } \\
\text { e pulse }\end{array}$ & $\begin{array}{l}1.1 \mathrm{mg} / \mathrm{dL} \text { at } 3 \\
\text { years }\end{array}$ \\
\hline
\end{tabular}

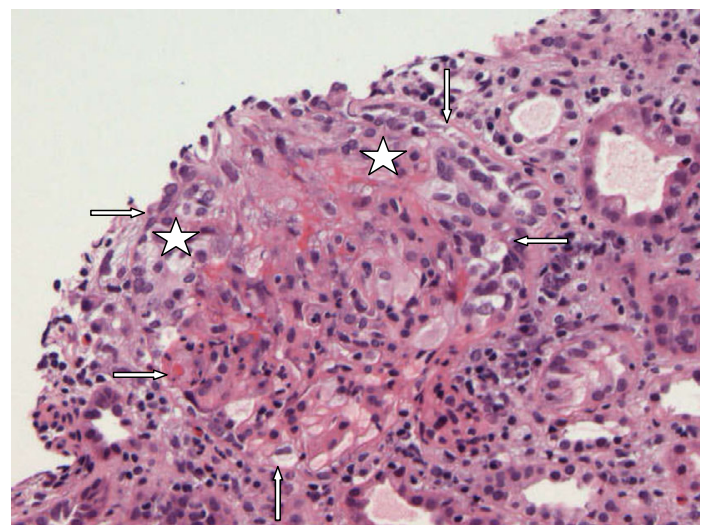

Figure. Glomerulus showing extra-capillary proliferation (*). The glomerular tuft shows some ischaemic collapse. Bowman's capsule (small white arrows). (Hematoxylin and Eosin staining, $\times 40)$.

show wide variations (7); in this case although the prevalence of ANCA is reported to be low (25) in these patients, we believe that ANCA should be checked in clinically relevant patients with RPGN in order to make a timely diagnosis and select the optimal treatment.

Written informed consent was obtained from the patient for publication of this case report and any accompanying images.

The authors state that they have no Conflict of Interest (COI).

\section{References}

1. Yurdakul S, Hamuryudan V, Yazici H. Behçet's syndrome. Curr Opin Rheumatol 16: 38, 2004.

2. Criteria for diagnosis of Behçet's disease. International Study Group for Behçet's Disease. Lancet 335: 1078, 1990.

3. Feigenbaum A. Description of Behçet's syndrome in the Hippokratic third book of endemic diseases. Br J Ophthalmol 40: 355, 1956.

4. Mutlu S, Scully C. The person behind the eponym: Hulusi Behçet (1889-1948). J Oral Pathol Med 23: 289, 1994.

5. Direskeneli H. Behçet's disease: infectious aetiology, new autoantigens, and HLA-B51. Ann Rheum Dis 60: 996, 2001.

6. El Ramahi KM, Al Dalaan A, Al Meshari K, Akhtar M. Renal involvement in Behçet's disease; review of 9 cases. J Rheumatol 25: 2256-2260, 1998.

7. Akpolat T, Akkoyunlu M, Akpolat I, Dilek M, Odabaş AR, Ozen S. Renal Behçet's disease: a cumulative analysis. Semin Arthritis Rheum 31: 317-337, 2002.

8. Kallenberg CGM. Pathogenesis of ANCA-associated vasculitides. Ann Rheum Dis 70 (Suppl 1): i59-i63, 2011.

9. Yang CW, Park IS, Kim SY, et al. Antineutrophilic cytoplasmic autoantibody associated vasculitis and renal failure in Behçet's disease. Nephrol Dial Transplant 8: 871-873, 1993.

10. Khan IH, Catto GRD, MacLeod AM. Antineutrophil cytoplasmic autoantibody associated vasculitis and renal failure in Behçet's disease. Nephrol Dial Transplant 9: 332, 1994.

11. Ohta S, Yokoyama H, Matsuda I, et al. A case of ANCA associated rapidliy progressive glomerulonephritis with oral aphta and erythema nodosum. Nihon Jinzo Gakkai Shi 36: 1184-1190, 1994 (in Japanese, Abstract in English).

12. Moises J, Torregrosa JV, Ybarra J, Oppenheimer F. Renal transplantation in a c-ANCA (+) patient with Behçet disease and rapidliy progressive glomerulonephritis. Clin Nephrol 61: 357-359, 2004.

13. Sarica K, Süzer O, Gürler A, Baltaci S, Ozdiler E, Dinçel C. 
Urological evaluation of Behçet patients and the effect of colchisine on fertility. Eur Urol 27: 39-42, 1995.

14. Rosenthal T, Weiss P, Gafni J. Renal involvement in Behçet's syndrome. Arch Intern Med 138: 1122-1124, 1978.

15. Calamia KT, Wilson FC, Icen M, Crowson CS, Gabriel SE, Kremers HM. Epidemiology and clinical characteristics of Behçet's disease in the US: a population-based study. Arthritis Rheum 61: 600-604, 2009.

16. Kansu E, Deglin S, Cantor R, Burke JF, Cho SY, Cathart RT. The expanding spectrum of Behçet syndrome: a case with renal involvement. JAMA 71: 408-410, 1977.

17. Landswehr DM, Cooke CL, Rodriguez GE. Rapidly progressive glomerulonephritis in Behçet's syndrome. JAMA 244: 1709-1711, 1980.

18. Olsson PJ, Gaffney E, Alexander RW, Mars DR, Fuller TJ. Proliferative glomerulonephritis with crescent formation in Behçet's syndrome. Arch Intern Med 140: 713-714, 1980.

19. Donnelly S, Johny S, Barre P. Crescentic glomerulonephritis in Behçet's syndrome-results of therapy and review of literature. Clin Nephrol 31: 213-218, 1989.
20. Sakemi T, Yoshiyuki T, Ikeda Y, Suzuki N, Nagasawa K. Endstage renal failure due to crescentic glomerulonephritis in a patient with Behçet's syndrome. Am J Nephrol 18: 321-324, 1998.

21. Kim SD, Kim SH, Kim HR, et al. Rapidly progressive glomerulonephritis in a patient with Behçet's disease: succesful treatment with intravenous cyclophosphamide. Rheumatol Int 25: 540-542, 2005.

22. Baleva M, Kolarov ZI, Nikolov K. Anineutrophil cytoplasmic autoantibody in two patients with Behçet's disease. Nephrol Dial Transplant 9: 876, 1994.

23. Jennette JC, Falk RJ. Pathogenesis of vascular and glomerular damage in ANCA positive vasculitis. Nephrol Dial Transplant $\mathbf{1 3}$ (Suppl 1): 16-20, 1998.

24. Falk RJ, Hogan S, Carey TS, Jenette JC. Clinical course of antineutrophil cytoplasmic autoantibody-associated glomerulonephritis and systemic vasculitis. The Glomerular Disease Colloborative Network. Ann Intern Med 113: 656-663, 1990.

25. Hmida MB, Hachica J, Kaddour N, et al. ANCA in Behçet's disease. Nephrol Dial Transplant 12: 2465-2466, 1997.

(C) 2016 The Japanese Society of Internal Medicine http://www.naika.or.jp/imonline/index.html 